\title{
A Rechargeable All-Solid-State Sodium Cell with Polymer Electrolyte
}

\author{
West, Keld; Zachau-Christiansen, Birgit; Jacobsen, Torben; Atlung, Sven
}

Published in:

Journal of The Electrochemical Society

Link to article, DOI:

$10.1149 / 1.2113725$

Publication date:

1985

Document Version

Publisher's PDF, also known as Version of record

Link back to DTU Orbit

Citation (APA):

West, K., Zachau-Christiansen, B., Jacobsen, T., \& Atlung, S. (1985). A Rechargeable All-Solid-State Sodium Cell with Polymer Electrolyte. Journal of The Electrochemical Society, 132(12), 3061-3062.

https://doi.org/10.1149/1.2113725

\section{General rights}

Copyright and moral rights for the publications made accessible in the public portal are retained by the authors and/or other copyright owners and it is a condition of accessing publications that users recognise and abide by the legal requirements associated with these rights.

- Users may download and print one copy of any publication from the public portal for the purpose of private study or research.

- You may not further distribute the material or use it for any profit-making activity or commercial gain

- You may freely distribute the URL identifying the publication in the public portal

If you believe that this document breaches copyright please contact us providing details, and we will remove access to the work immediately and investigate your claim. 


\author{
K. West, B. Zachau-Christiansen, T. Jacobsen, ${ }^{*}$ and S. Atlung* \\ Fysisk-Kemisk Institut, The Technical University of Denmark, DK 2800 Lyngby, Denmark
}

\section{INTRODUCTION}

Secondary lithium cells with intercalation or insertion materials as positive electrades are now an extensively studied subject. However, only few papers covering the corresponding sodium systems have yet appeared. Ostensibly this is due to the lack of reversible sodium lelectrolyte half-cells functioning below $200^{\circ} \mathrm{C}$. At higher temperatures most electrode materials will react via displacement reactions, which generally have lower electrode potentials and do not possess the inherent reversibility of intercalation reactions.

Liquid organic electrolytes consisting of NaI dissolved in propylene carbonate have been used for electrochemical preparation of sodium intercalated TjS $(1,2)$. The Exxon group has cycled both $\mathrm{Na} / \mathrm{TiS}_{2}$ and $\mathrm{Na}^{\mathrm{MOS}} \mathrm{S}_{3}$ using sodium triethyl (N-pyrrol) borate dissolved in 1.3-dioxolane as electrolyte $(3,4)$. Most other groups have chosen to use two-electrolyte systems with an ionic conducting ceramic membrane. This membrane separates molten sodium from the liquid electrolyte forming contact to the active material in the positive electrode (5).

In this communication cycling of a cell with solid sodium in contact with a polymer electrolyte and with amorphous $\operatorname{Mos}_{3}$ as positive electrode is reported.

\section{EXPER I MENTAL}

Amorphous $\mathrm{MoS}_{3}$ was prepared by thermal decomposition of $\left(\mathrm{NH}_{4}\right)_{2} \mathrm{MOS}_{4}$ as described by Jacobson et $a 1$ (3).

Sodium electrodes were made by pressing a layer of sodium onto a Ni foil, using polyethylene sheets to aid the spreading. In this way smooth layers of

*Electrochemical Society Active Member. sodium with thicknesses between $50 \mu \mathrm{m}$ and $100 \mu \mathrm{m}$ were obtained.

Polymer electrolyte sheets $(\approx 30 \mu \mathrm{m})$ were prepared by evaporation of acetonitrile solutions of poly-(ethylene oxide) (PEO) and the proper amount of NaI, recrystallized from acetonitrile and vacuumdried at $180^{\circ} \mathrm{C}$. The PEO (WSR 301 Polyox, $M W=4 * 10^{6}, B D H$ ) was used as received. The films were prepared and handled in an argon filled dry box. The NaI concentration in the films used corresponded to a $\mathrm{Na} / 0$ ratio of $1: 10$. with this electrolyte, the operating temperature of the cell is confined to the interval between $98^{\circ} \mathrm{C}$ (melting of sodium) and $65^{\circ} \mathrm{C}$, as the electrolyte conductivity decreases rapidly below this temperature.

Composite $\mathrm{MoS}_{3}$ electrode films $(\simeq 50 \mu \mathrm{m})$ with the overall composition: 72 w/o $\mathrm{MOS}_{3}, 20 \mathrm{w} / 0 \mathrm{PEO}$, and $8 \mathrm{w} / 0 \mathrm{NaI}$ were prepared by evaporating acetonitrile suspensions/solutions of the ingredients onto nickel foils. In some cases graphite was added as conductive diluent, but no improvement of cell. performance at these very low current densities was achieved.

The cell was mounted with spring load in a Ni-plated brass container sealed with a viton 0-ring. This container was heated in air to $90^{\circ} \mathrm{C}$ in a Buchi TO-50 oven.

\section{RESULTS}

The first two cycles of the cell

$$
\mathrm{Na} / \mathrm{PEO}-\mathrm{NaI}(10: 1) / \mathrm{MOS}_{3}
$$

are shown in fig. 1. The current density used for discharge and charge was 15 $\mu \mathrm{A} / \mathrm{cm}^{2}$ in these cycles, corresponding to a stoichiometric discharge time of $45 \mathrm{~h}$. The cell was discharged to $1.5 \mathrm{~V}$. 


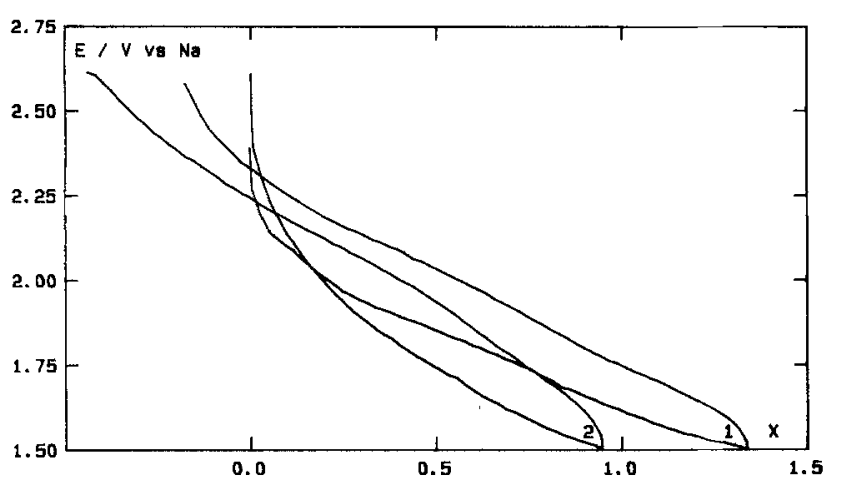

Fig. 1. Initial cycles of the cell $\mathrm{Na}$ NaI-PEO (10:1) / MOS at 15 $\mu \mathrm{A} / \mathrm{cm}^{2}$. Charge recalculated as $X=\mathrm{Na} / \mathrm{MO}$ based on total Moanalysis of cell.

and recharged to $2.6 \mathrm{~V} V \mathrm{Na}$. It is seen that the coulombic cycling efficiency (the ratio between discharge and charge capacity) is considerably less than unity, possibly due to disproportionation of the electrolyte. An advantage of using iodide-containing electrolytes in alkali metal batteries might be that the iodine liberated during overcharge recombines with the alkali metal and thereby scavenges the negative electrode of developing dendrites.

The discharge curve is smooth as expected for an amorphous electrode material, and $1.4 \mathrm{Na} / \mathrm{Mo}$ is inserted during the first discharge. Previously discharge capacities of up to $3 \mathrm{Na} / \mathrm{Mo}$ have been achieved (4), but the capacity has been shown to be sensitive to the details of the Mos 3 synthesis (6). The stoichiometric capacity calculated from the first discharge is $290 \mathrm{wh} / \mathrm{kg}$.

The development of the discharge capacity upon cycling is shown on Eig. 2 . The charge and discharge current used was $150 \mu \mathrm{A} / \mathrm{cm}^{2}$ in cycle 3 to 9 , and 15 $\mu \mathrm{A} / \mathrm{cm}^{2}$ in the other cycles. Despite the rapid decrease in cell capacity, a total number of $10 \mathrm{Na} / \mathrm{Mo}$ have been cycled during the lifetime of this cell, and the available amount of sodium has been cycled 1.5 times. This shows that, even close to its melting point, sodium forms a sufficiently

Manuscript submitted July 11, 1985; revised manuscript received Oct. 3, 1985.

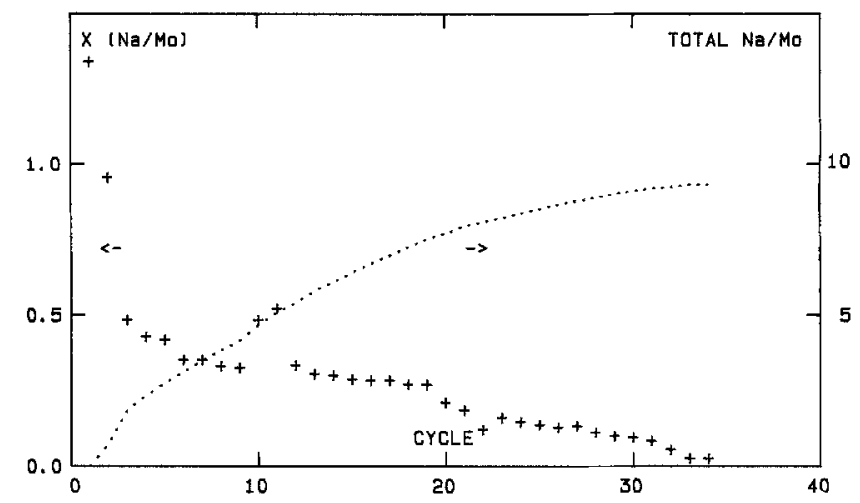

Fig. 2. Discharge capacity as function of cycle number. The total number of $\mathrm{Na}$ cycled per $\mathrm{Mo}$ is also shown.

stable interface with a pEo-electrolyte to allow reversible operation of this electrode. Possibly the formation of a passive sodium ion conducting film on the interface is responsible for this stability.

It is thus concluded that solid state sodium batteries might be feasible by extension of lithium battery technology, especially when electrolytes with better conductivity and more reversible electrode materials are developed.

\section{REFERENCES}

1. D.A. Winn, J.M. Shemilt, and B.C.H. Steele, Mat. Res. Bull. 11, 559 (1976).

2. D. Cherns and G.P. Ngo, J. Solid state Chem. 50, 7 (1983).

3. A.J. Jacobson, R.R. Chianelli, S.M. Rich, and M.S. Whittingham, Mat. Res. Bull. 14, 1437 (1979).

4. G.H. Newman and L.D. Klemann, $J$. Electrochem. Soc., 127, 2097 (1980).

5. K.M. Abraham, solid state ronics, 7 , 199 (1982).

6. R. Williams, D, Shen, S.P.S, Yen, and R.B. Somoano, Extended Abstract No. 74, Electrochem. Soc. Meeting, washington (1983).

The Technical University of Denmark assisted in meeting the publication costs of this article. 